\title{
MSTTR
}

\section{Plasma Studies on a Duopigatron Ion Source}

\author{
C. C. Tsai \\ P. M. Ryan \\ W. L. Stirling
}




\section{DISCLAIMER}

This report was prepared as an account of work sponsored by an agency of the United States Government. Neither the United States Government nor any agency Thereof, nor any of their employees, makes any warranty, express or implied, or assumes any legal liability or responsibility for the accuracy, completeness, or usefulness of any information, apparatus, product, or process disclosed, or represents that its use would not infringe privately owned rights. Reference herein to any specific commercial product, process, or service by trade name, trademark, manufacturer, or otherwise does not necessarily constitute or imply its endorsement, recommendation, or favoring by the United States Government or any agency thereof. The views and opinions of authors expressed herein do not necessarily state or reflect those of the United States Government or any agency thereof. 


\section{DISCLAIMER}

Portions of this document may be illegible in electronic image products. Images are produced from the best available original document. 
Printed in the United States of America. Available from National Technical Information Service

U.S. Department of Commerce

5285 Port Royal Road, Springfield, Virginia 22161

Price: Printed Copy $\$ 4.00$; Microfiche $\$ 3.00$

This report was prepared as an account of work sponsored by the United States Government. Neither the United States nor the Energy Research and Development Administration/United States Nuclear Regulatory Commission. nor any of their employees, nor any of their contractors, subcontractors, or their employees, makes any warranty, express or implied, or assumes any legal liability or responsibility for the accuracy, completeness or usefulness of any information, apparatus, product or process disclosed, or represents that its use would not infringe privately owned rights. 
Contract No. W-7405-eng-26

FUSION ENERGY DIVISION

PLASMA STUDIES ON A DUOPIGATRON ION SOURCE
C. C. Tsal
P. M. Ryan
W. L. Stirling

Date Published: January 1977

Prepared by the

OAK RIDGE NATIONAI LABORATORY

Oak Ridge, Tennessee 37830

operated by

UNION CARBIDE CORPORATION

for the

ENERGY RESEARCH AND DEVELOPMENT ADMINISTRATION 


\section{THIS PAGE}

\section{WAS INTENTIONALLY \\ LEFT BLANK}




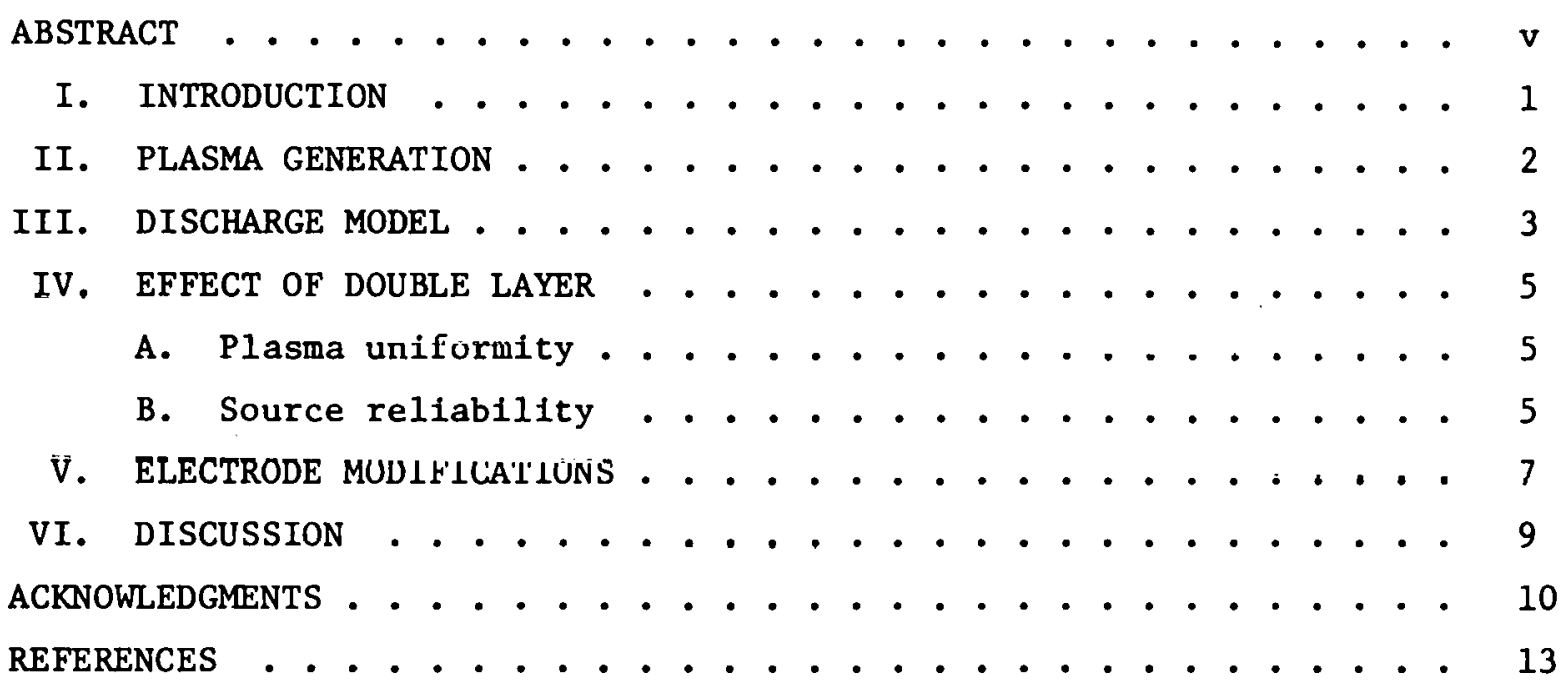




\section{THIS PAGE}

\section{WAS INTENTIONALLY \\ LEFT BLANK}




\author{
PLASMA STUDIES ON A DUOPIGATRON ION SOURCE* \\ C. C. Tsai, P. M. Ryan, and W. L. Stirling \\ Oak Ridge National. Laboratory \\ Oak Ridge, Tennessee 37830
}

\begin{abstract}
In an effort to develop a plasma source capable of producing a dense, quiescent, uniform plasma for extracting tens of amperes of hydrogen ions, experimental and theoret1cal studies on a duoPIGatron ion source have been pursued. A study of plasma generation in the duoPIGatron was begun and a discharge model was subsequently developed to explain observed source behavior. The discharge model is based on two plasmas, a cathode plasma and a PIG plasma separated by a double layer of ions and electrons, and is similar to the existing model for a duoplasmatron. This discharge model 1s reviewed and the importance of the double layer on plasma generation in the duoPIGatron is discussed. Source electrode modifications suggested by the model resulted in a low noise level of about $\pm 5 \%$ and a low-density nonuniformity of about $\pm 10 \%$ over a $10-\mathrm{cm}$ diameter at a h1gh hydrogen plasma density of roughly $2 \times 10^{12} \mathrm{~cm}^{-3}$.
\end{abstract}




\section{INTRODUCTION}

Neutral beam injection heating experiments in the Adiabatic Toroidal Compressor (ATC) and the Oak Ridge Tokamak (ORMAK) have demonstrated that energetic neutral beams can significantly heat toroidal plasmas. ${ }^{1,2}$ The duoPIGatron ion source developed at the Oak Ridge National Laboratory (ORNL) is one of the prime candidates for developing future high power neutral beam injectors, e.g. for Princeton Large Torus (PLT), the Poloidal Divertor Experiment (PDX), and the Tokamak Fusion Test Reactor (TFTR) at Princeton Plasma Physics Laboratory (PPPL); for Doublet III at General Atomic Company; and for ORMAK Upgrade at ORNL. For these applications, the plasma source developed should be capable of generating a dense, quiescent, uniform plasma for producing tens of amperes of hydrogen or deuterium ion current in the energy range of tens to hundreds of kilo-electron volts. To fulfill these basic requirements, a study of the plasma generation and discharge mechanism of duoPIGatron Ion sources has been undertaken. A.discharge model has been developed to explain the observed source behavior. This discharge model is based on two plasmas, a cathode plasma and a Philips ion gauge (PIG) plasma separated by a double layer of ions and electrons, and is similar to an existing model for a duoplasmatron. ${ }^{3}$ We bricfly, review the plasma generation and discharge model, discuss the key effect of the double layer, and report the electrode modifications which have been employed for Improving the source performance. 


\section{PLASMA GENERATION}

Figure 1 shows a sketch of a 10-cm (grid diameter) duoPIGatron ion source and its associated electrical connections. It consists of a filament; an intermediate electrode; two anodes, numbered 1 and 2; and a target cathode. (Other researchers refer to the target cathode as the plasma electrode or screen electrode.) Pulsed arc voltage is applied between the anodes and filament, while both the intermediate electrode and target cathode are self-blased through high resistance connections to the anode. The intermediate electrode serves as a magnetic pole to provide an inhomogeneous axial magnetic fleld in the anode regions.

For normal operation, primary electrons emitted from the filament produce a cathode plasma in the intermediate electrode chamber. Some of these electrons are accelerated through the intermediate electrode channel and into the anode region. These energetic electrons are constrained by the magnetic field and oscillate between the cathode plasma and target cathode. They initiate and maintain a so-called PIG discharge or a reflex discharge. Because of their high energy and long path length, they produce a dense PIG plasma and become the chief ionizers in the PIG region. 'l'he ions so created are formed into an ion beam by the extraction electrodes. In the closely coupled, gas cell, this ion beam is converted into an energetic'neutral beam for heating a plasma such as the one in ORMAK. 
III. DISCHARGE MODEL

The general operating range of the source variables is listed in Table I. The hydrogen pressure is about 50 mTorr in the intermediate electrode chamber and about $5 \mathrm{mTorr}$ in the target cathode region. The applied magnetic field is about 200 to $400 \mathrm{G}$ in the intermediate electrode region and about 10 to $20 \mathrm{G}$ in the target cathode region. The arc voltage is up to $150 \mathrm{~V}$ and arc current is up to $220 \mathrm{~A}$. The corresponding electrode potential is also listed in the table.

Together with the results obtained from measurements on an axial probe, these data can be utilized to depict an axial potential distribution in the source, as shown in Fig. 2. This distribution confirms that the the source plasma is composed of a cathode plasma and a PIG plasma separated by a double layer.

The cathode plasma results from the cathode discharge located within the intermediate electrode chamber. This discharge is initiated and sustained by the primary electrons emitted from the filament. In this region, which is free of magnetic flelds, the discharge intensity is essentially determined by the discharge current and gas pressure because of the low electron energy. Normally, the cathode plasma is separated from the filament by a duulle layer of iono and electrons, and from the walls of the intermediate electrode by a single layer of ions. Thus the plasma potential is greater than the filament potential by the cathode fall. On the other hand, the floating intermediate electrode hehaves as a Langmuir probe and has its potential, $V_{I E}$, fixed by the plasma potential and electron temperature. Consequently, the potential difference between the intermedtate electrode and the fllament, $V_{I E}-V_{F}$, is a few volts below the cathode fall, which is larger than the ionization potential of the working gas (i.e. hydrogen). This may explain why the values of $\left(V_{I E}-V_{F}\right)$ for the normal operation of the source are within the range of 20 to $30 \mathrm{~V}$, as listed in Table I.

The PIG plasma results from the PIG discharge which is located in the region enclosed by the anodes, the cathode plasma, and the target cathode. The discharge is essentially initiated and maintained by the electrons originating from the cathode plasma. These electrons gain 
at least an energy corresponding to the potential drop across the double layer between the two plasmas. In addition, they are constrained by the applied magnetic field and oscillate between the cathode plasma and target cathode. With sufficiently high energy and long path length, they establish a strong PIG discharge and become the chief ionizers. Thus, the discharge intensity is mainly affected by the applied magnetic field, the arc voltage, and the discharge current.

The double layer not only sustains the potential difference between the two plasmas but also ensures the arc conduction thrnugh them. The arc conduction is maintained by both electrons and lons flowing through the double layer. The electrons originate from the cathode plasma and are accelerated into the double layer, whlle the fons are created in the PIG discharge and diffuse towards the intermediate electrode and drift into the double layer. Owing to the mass difference between the Ions and the electrons, the modified Langmuir's stability criterion for the double layer is $^{4,5}$

$$
J_{e} / J_{+} \leqslant \gamma\left(M_{+} / M_{e}\right)^{1 / 2}=k \text {, }
$$

where $J_{\theta}$ is the electron current density in the cathode plasma, $J_{+}$is the ion current density in the PIG plasma, $\gamma$ is a constant about $1 / 2$, and $M_{+}$and $M_{e}$ are the 1 on and electron masses, respectively. The constant $k$ is about 30 for the hydrogen molecular 1on. Thus, the arc current is dominated by the electron current.

In summary, the cathode plasma works as an electron source, supplying ionizing electrons to the PIG discharge, and the PIG plasma works as an ion source, supplying ions to the extraction electrodes for forming a useful ion beam. The double layer works as a controller: It controls the density and uniformity of the PIG plasma and influences source reliability. This point is further clarified in Sec. IV. 


\section{EFFECT OF DOUBLE LAYER}

In practice, the spatial distribution of the electron current density, $J_{e}$, in the cathode plasma and of the ion current density, $J_{+}$, In the PIG plasma changes greatly with the arc condition. To satisfy the stability criterion given in Eq. 1, the shape of the double layer will vary with the intensity of both discharges. For example, it can be either concave, flat, or convex toward the PIG plasma, as shown in Fig. 3 . The curvature of the double layer can greatly affect the plasma density and uniformity and the source rellability. In the following, we discuss these effects for a concave double layer.

\section{A. Plasma uniformity}

Normally, for producing a useful ion beam, the arc condition is adjusted to produce a dense PIG plasma. Often the cathode discharge is too weak and the double layer bulges towards the cathode plasma, as shown in Fig: 4. This concave double layer focuses the ionizing electrons towards the axis. The electrons are then confined by the magnetic fleld and produce a dense arc column, close to the axis. The resulting axial focusing of electrons creates a highly nonuniform PIG plasma, as shown in Fig. 5, curve I. The plasma uniformity shown by curve II in this figure has been improved substantially through use of an axial button of the proper size located on the intermediate electrode snout. The axial button is capable of diverting the arc column from on-axis to offaxis; its function is described in detail in Sec. V.

\section{B. Source reliability}

The concave double layer (Fig. 4) not only produces a nonuniform PIC plasma but also increases the radial electric field in the outer arc column of the PIG region. The resulting $E \times B$ rotation can lead to an undesirable charge separation in the plasma and to flute instability 6 because of the different collision frequency between electron-gas and ion-gas collisions. This may account for the observed high noise on the arc current whenever the applied magnetic field is too strong. If the magnetic field is further raised to an undesirably high 
value, a large amplitude of noise modulation (rapid and erratic discharge interruptions) on the arc current, about $\pm 100 \%$, can suddenly set in. This undesirable noise level could be due to the fluctuation of the double layer. Under this situation, there is a great increase in the number of electrons entering the double layer radially from the outer region of the cathode plasma and being reflected by the strong mirror magnetic field at the entrance region of the intermediate electrode channel. The associated decrease of ionizing electrons weakens the PIG discharge. To satisfy the stability criterion of the double layer as given by Eq. 1, the shape of Lhe duuble layer may vary as those shown in Fig. 3. 3uch duuble layer fluctuations can be sustained during the whole arc pulse and cause the undesirably high noise level observed. In addition, the associated bombardments of backstreaming ions may well account for the rapid burnout of the filament under such conditions. Such an undesirable source behavior can appear whenever the operating conditions are outside the normal range. Typical examples of such abnormal conditions are: the applied magnetic field is too strong, the anode voltage and/or gas pressure is too low, and the electron emission from the filament is insufficient. These problems have been alleviated substantially through use of proper electrode modifications, described in Sec. V. 


\section{ELECTRODE MODIFICATIONS}

Based upon the understanding of the plasma generation in the duoPIGatron and the instability mechanism, the proper electrode modifications have been employed to improve the source plasma. In addition to an arc stabilizer, ${ }^{6}$ we have utilized the following elements: an axial button, a ring insert, and multiple filaments. Apparently, the configurations, dimensions, locations, and materials of these elements are very important. Their functions are summarized below.

\section{A. Axial copper button}

Figure 6 shows an axial copper button in the intermediate electrode snout. The buttion can improve plasma uniformity (Fig. 5) by reducing the passage of axial electrons and ions and diverting the arc column from onaxis to off-axis. In addition, it can intensify the PIG discharge by increasing the kinetic energy of lonizing electrons through an increase of arc impedance and intensify the cathode discharge by increasing the gas pressure in the cathode region through the reduction of gas conductance without an increase in gas throughput. Moreover, by helping to stabilize the double layer, the button can reduce the noise level and improve the source reliability.

\section{B. Copper and iron ring insert}

As shown in Fig. 6, the copper and iron tapered ring insert is capable of stabilizing the double layer and reducing noise level. The 1nsert can also modify the distribution of the applied source magnetic field and consequently is able to intensify the PIG discharge and improve plasma density and uniformity near the extraction region.

\section{Multiple filaments}

The multiple off-axis filaments chiefly serve to prolong filament lifetime by reducing the bombarding damage of backstreaming axial ions. The associated increase in emission area raises arc current capability. Consequently, the multifilament intensifies the cathode discharge and 
helps to stabilize the double layer, reducing the noise level and $1 \mathrm{~m}-$ proving the source reliability.

With these significant modifications, the $10-\mathrm{cm}$ duoPIGatron ion source achieved the desirable performance shown in Table II. The plasma uniformity of $\pm 10 \%$ is much better than the $\pm 30 \%$ over the $7-\mathrm{cm}$ grid diameter in a $7-\mathrm{cm}$ duoPIGatron ion source. ${ }^{6}$ The noise level is down to about $\pm 5 \%$ from $\pm 30 \%$ in a $7-\mathrm{cm}$ source. Filament lifetime has been prolonged to several months of normal operation. 
VI. DISCUSSION

The discharge model is consistent with the observed source behavior of the duopIGatron ion source. We will continue our study to further improve our understanding about this source and follow the guidance of this model to improve the source performance. The encouraging performance of the duoPIGatron source with the 10-cm-diam extraction pattern makes us very optimistic and confident in developing larger plasma sources. (15 cm, $20 \mathrm{~cm}$, and $25 \mathrm{~cm}$ in diameter) for future high power neutral beam injectors. Recently, we have successfully developed a 15-cm source for producing a 30-A hydrogen ion beam at $27 \mathrm{keV}$. Further details will be reported in the near future. The techniques developed and learned from this source can be applied to other fon sources, particularly the duoplasmatron ion source. 


\section{ACKNOWLEDGMENTS}

The authors would like to express their appreciation to R. C. Davis for his valuable technical assistance. We also acknowledge fruitful discussions with H. H. Haselton, G. Schilling, L. D. Stewart, and other colleagues in the Plasma Heating and Fueling Section. 
TABLE 1

OPERATING CONDITION OF A 10-CM SOURCE

WORKING GAS

GAS PRESSURE

ARC VOLTAGE

ARC CURRENT

MAGNETIC FIELD
HYDROGEN

50 mTorr I.E. Chamber

$\sim 5$ MTORR T.C. REgION

UP TO $150 \mathrm{~V}$

UP TO $220 \mathrm{~A}$

$\sim 200$ to 400 G I.E. REgion

$\sim 10$ TO $20 \mathrm{G}$ T.C. REgION

\section{ELECTRODE POTENTIALS}

$$
\begin{aligned}
V_{F} & \equiv 0 ; & V_{I E} & =\sim 20 \text { T0 } 30 \mathrm{~V} \\
V_{T C} & =\sim 50 \text { т0 } 80 \mathrm{~V} ; & V_{A 1, A 2} & =\sim 80 \text { To } 150 \mathrm{~V}
\end{aligned}
$$




\section{TABLE 2}

\section{PERFORMANCE OF A 10 CM SOURCE}

Plasma Uniformity

Noise LeVel

FILAMENT LIFETIME

High Voltage

Beam Current

Pulse DuRation $\pm 10 \%$ OVER 10 -CM GRID, COMPARED TO

$\pm 30 \%$ IN 7 - CM SOURCE

$\pm 5 \%$, FROM $\pm 30 \%$ IN $7-\mathrm{CM}$ SOURCE

GREATER THAN 6 WEEKS

$40 \mathrm{KEV}$

15 A AT $40 \mathrm{KEV}$ AND $250 \mathrm{MSEC}$

750 MSES AT 30 K.EV AND 9 A 


\section{REFERENCES}

${ }^{*}$ Research sponsored by the Energy Research and Development Administration under contract with the Union Carbide Corporation.

1

0. B. Morgan, Paper VI-1, and T. C. Jernigan et a1., Paper VI-9 in Proc. 2nd Symposium on Ion Sources and Formation of Ion Beams (1974).

2. A. Berry, Bull. Am. Phys. Soc. Series II 20 (20), 1332 (1975).

3

${ }^{3}$ C. LeJeune, Nucl. Instrum. Methods 116, 417-428 and 429-443 (1974).

4. Langmuir, Phys. Rev. 33, 930 (1929).

5. G. Andrews and J. E. Allen, Proc. R. Soc. 320, 457 (1971).

${ }^{6}$. C. Davis et al., Rev. Sci. Instrum. 46 (5), 576 (1975). 
FIGURE LEGENDS

FIG. 1. 10-cm prototype duoPIGatron ion source.

FIG. 2. Discharge model and axial potential distribution in a duoPIGatron.

FIG. 3. Typical shapes of double layer.

FIG. 4. Effect of concave double layer.

FIG. 5. Typical density profiles with and without utilizing an axial copper button.

FIG. 6. Sketch of an axial button, ring insert, and multiple filaments. 


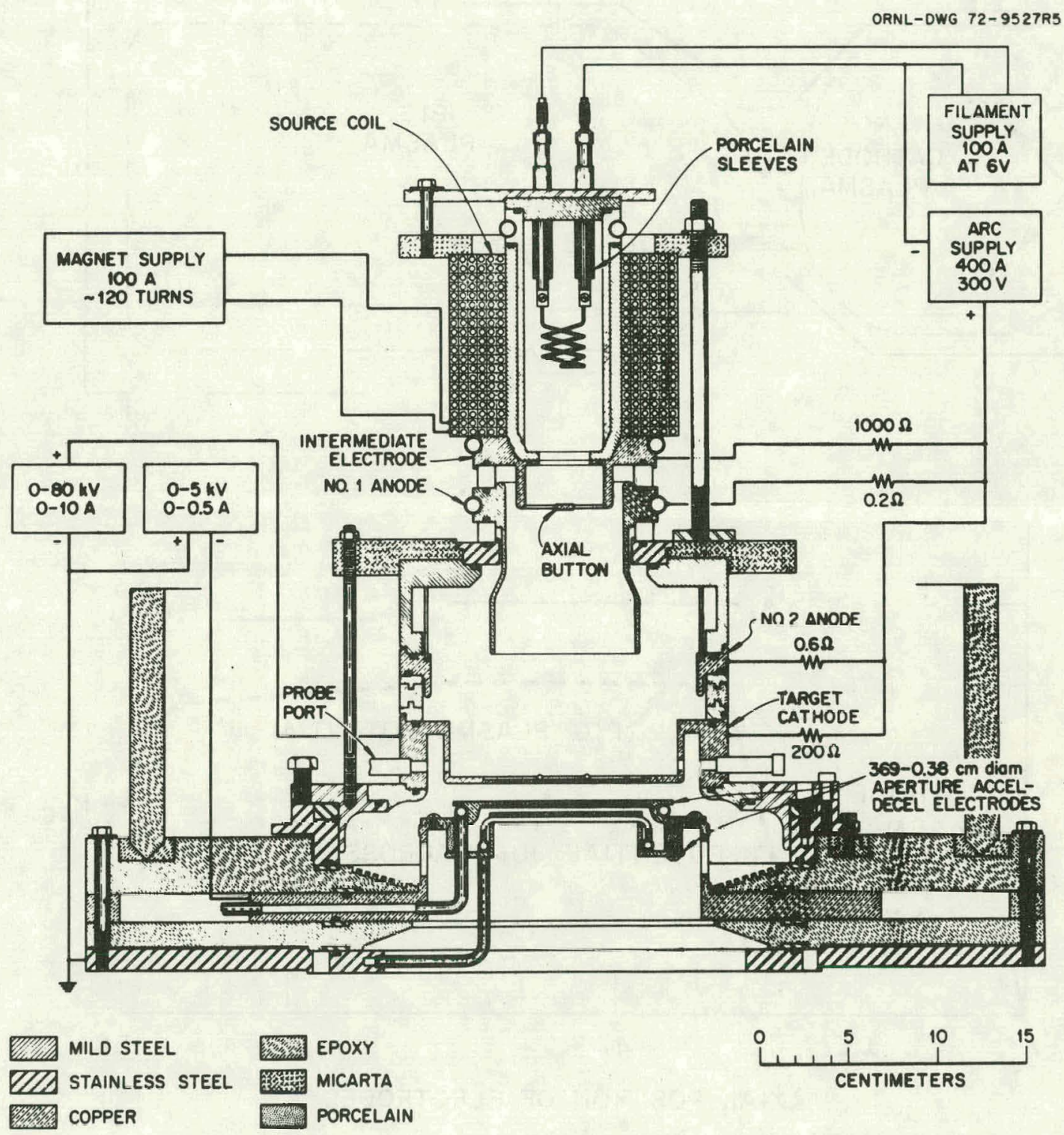

FIG. 1. 10-cm prototype duoPIGatron ion source. 
ORNL-OWG 75-6125
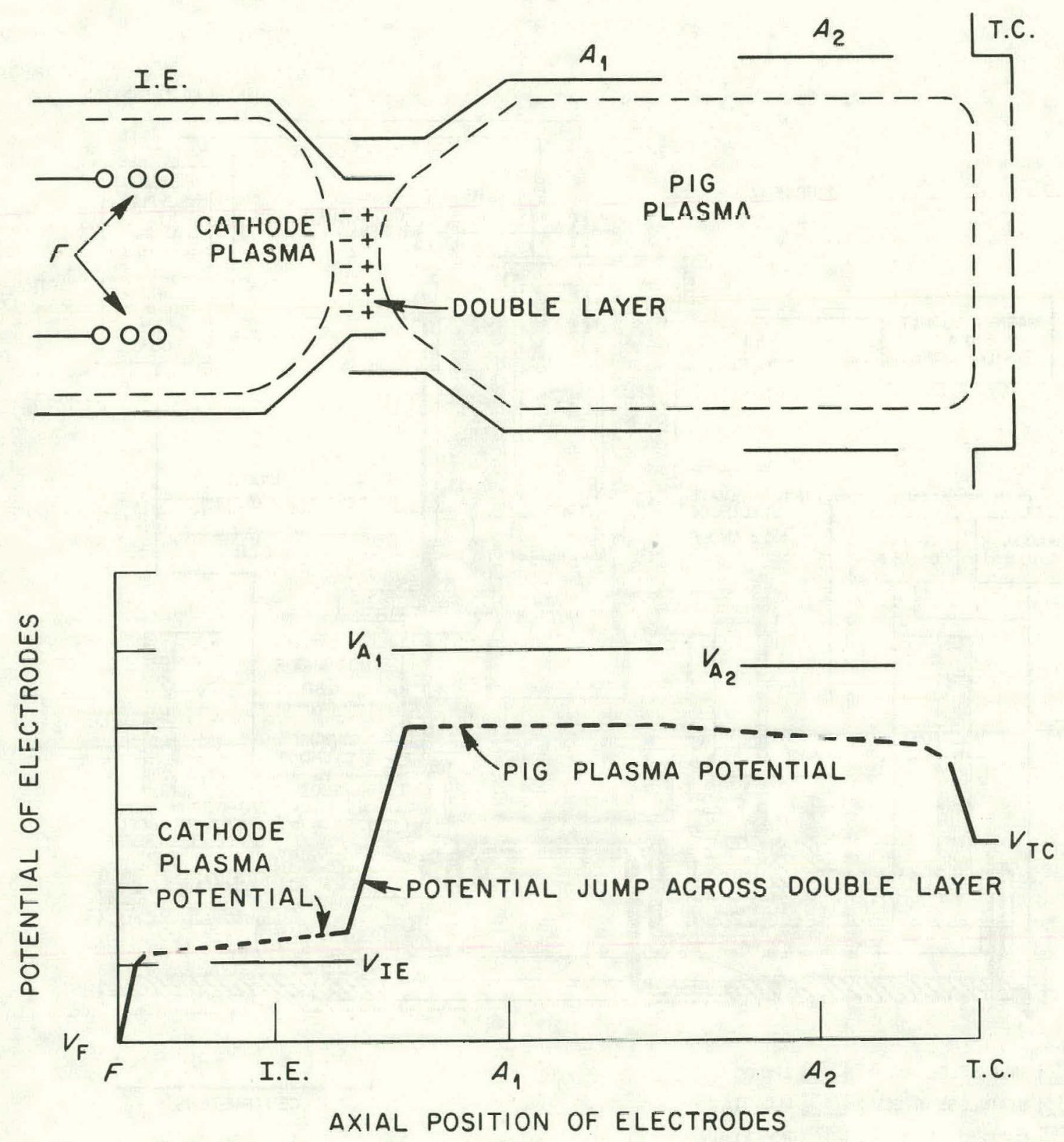

FIG. 2. Discharge model and axial potential distribution in a duoPIGatron. 
ORNL- DWG 75-10548
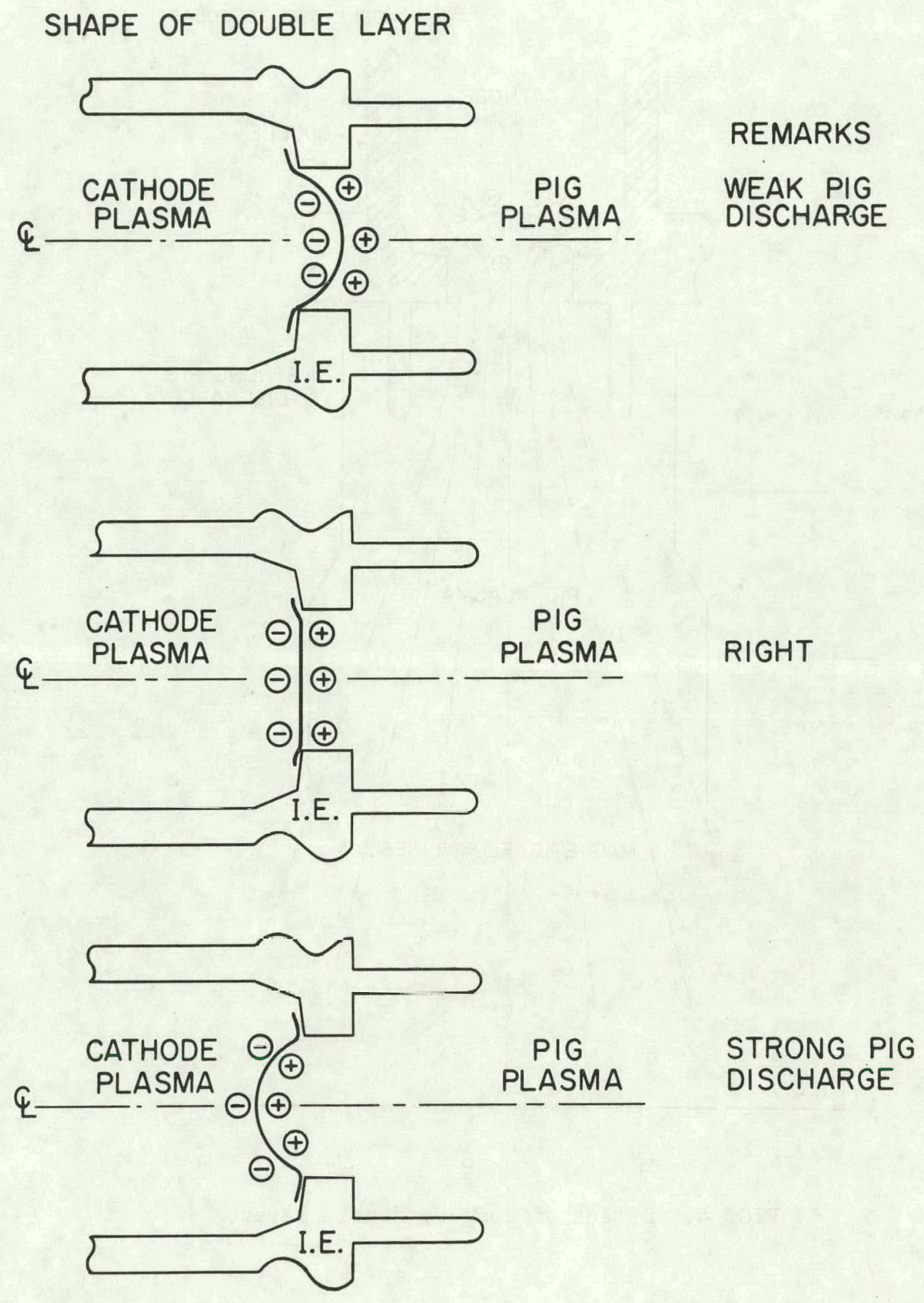

FIG. 3. Typical shapes of double layer. 


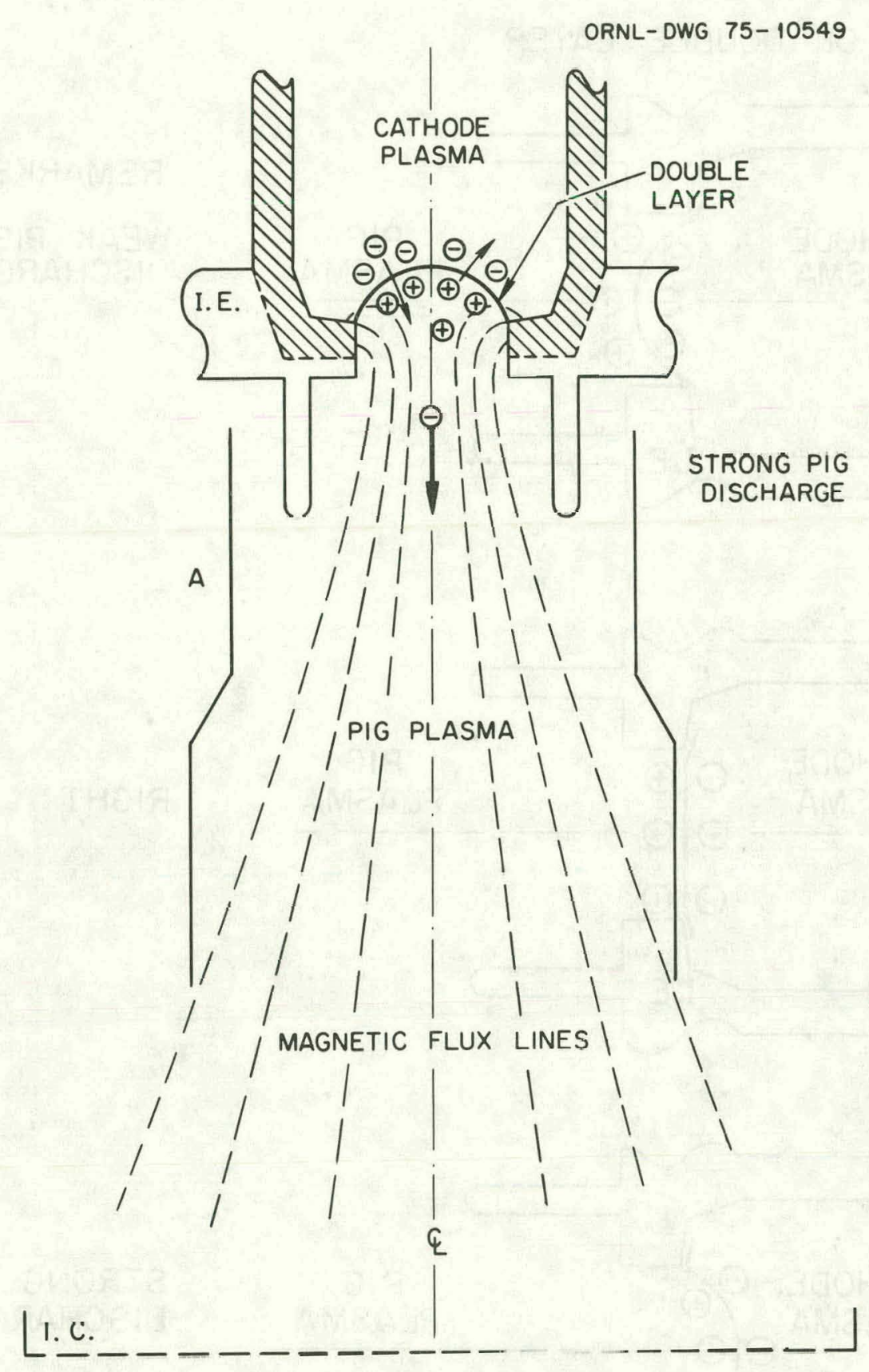

FIG. 4. Effect of concave double layer. 
ORNL-DWG 75-10550

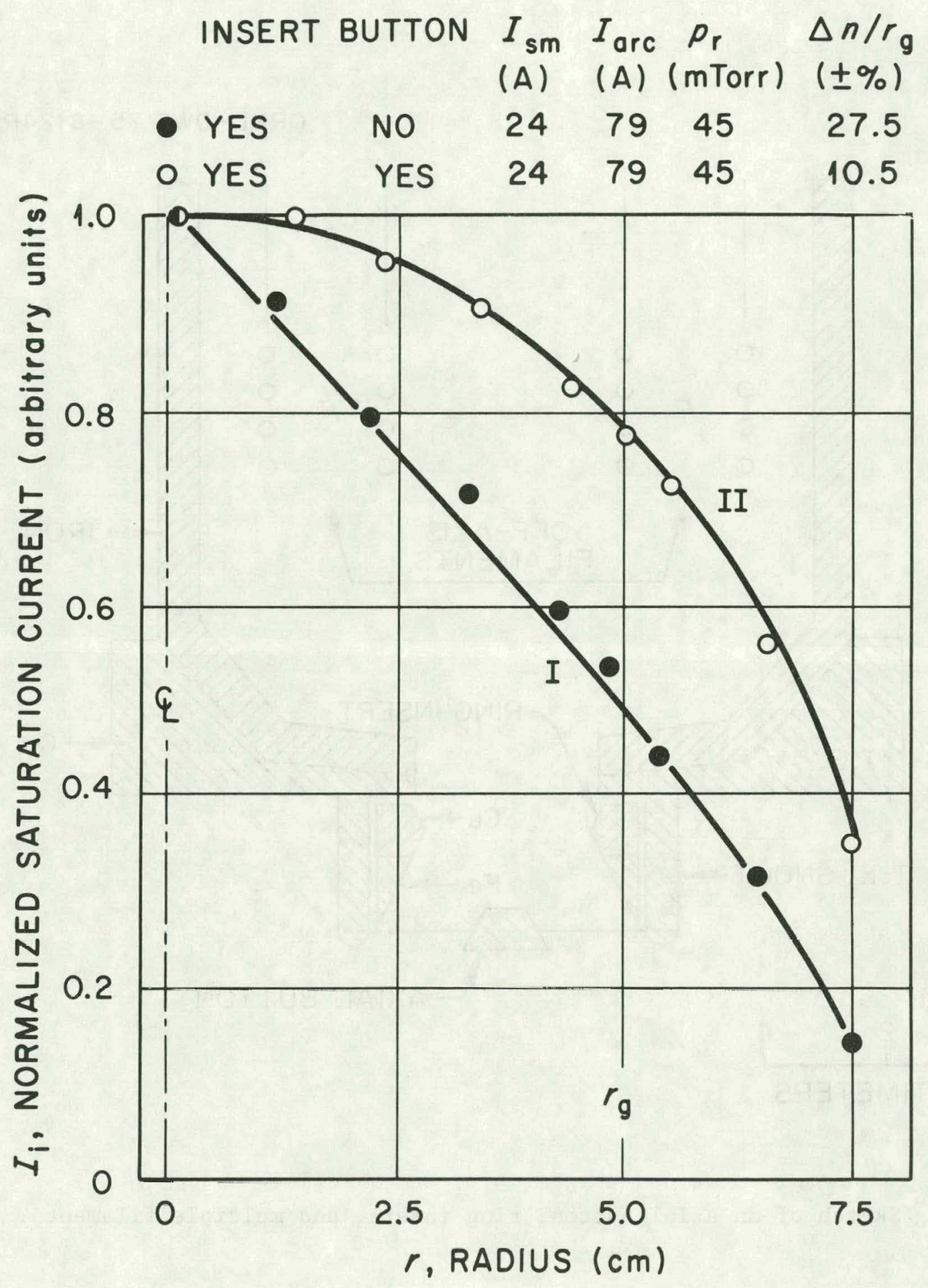

FIG. 5. Typical density profiles with and without utilizing an axial copper button. 


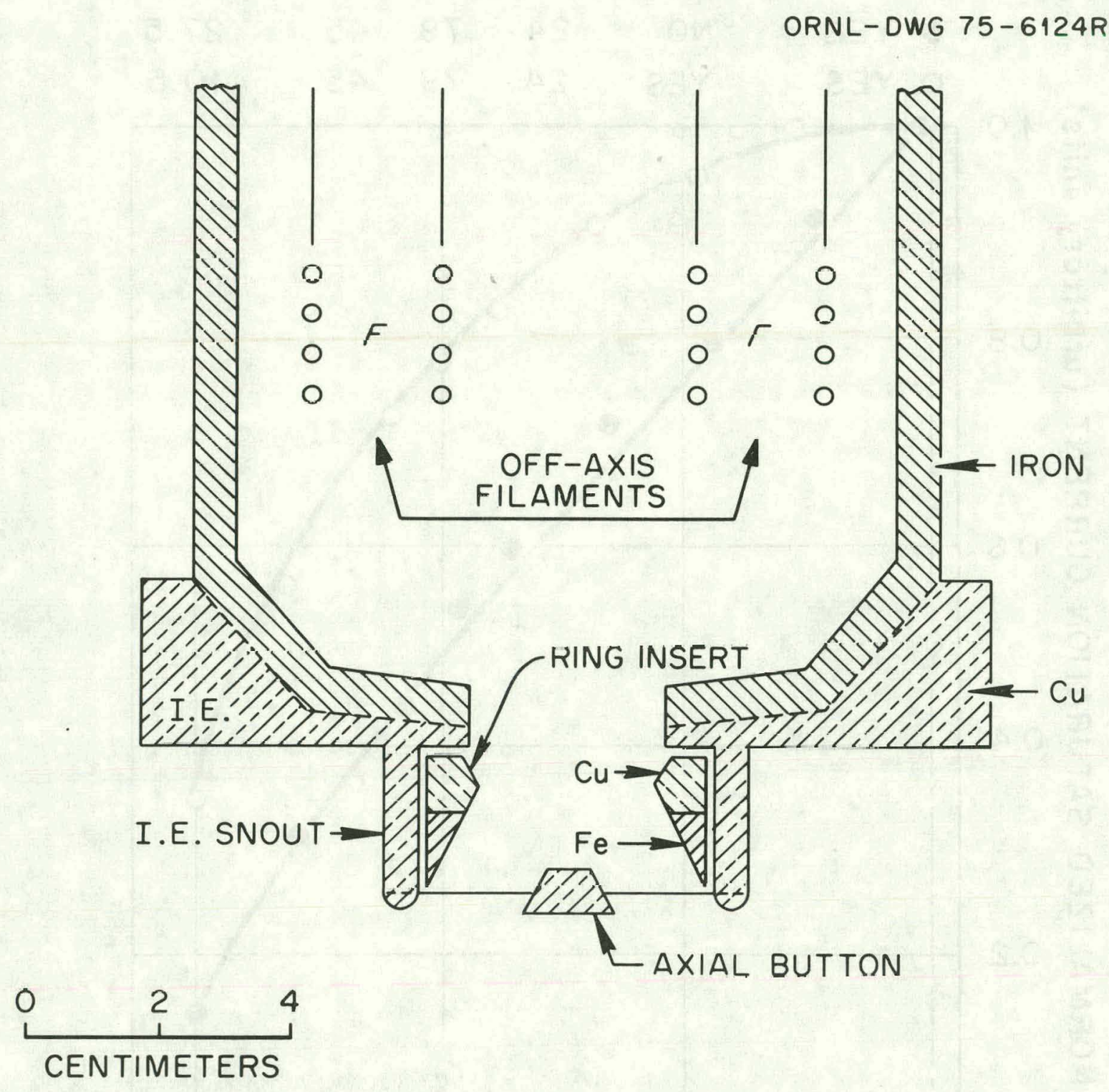

FIG. 6. Sketch of an axial button, ring insert, and multiple filaments. 


\section{INTERNAL DISTRIBUTION}

1. G. C. Barber

2. L. A. Berry

3. J. D. Callen

4. J. F. Clarke

5. W. K. Dagenhart

6. R. A. Dand 1

7. R. C. Davis

8. C. A. Foster

9. R. L. Grisham

10. H. H. Haselton

11. P. N. Haubenreich

12. T. C. Jernigan

13. G. G. Kelley

14. J. Kim

15. H. M. Long

16. J. F. Lyon

17. F. B. Marcus

18. D. G. McAlees

19. S. L. Milora

20. 0. B. Morgan
21. N. S. Ponte

22. M. Roberts

23. J. A. Rome

24. M. W. Rosenthal

25. P. M. Ryan

26. D. E. Schechter

27. G. Schilling

28. D. Stelner

29. L. D. Stewart

30. W. L. Stirling

31-41. C. C. Tsai

42. J. H. Whealton

43. R. E. Wright

44-45. Central Research Library

46. Document Reference Section

47-48. Laboratory Records Department

49. Laboratory Records, ORNL-RC

50. ORNL Patent Office

51-52. Fusion Energy Division Library

53. Fusion Energy Division Reports

\section{EXTERNAL DISTRIBUTION}

54. J. W. Beal, Development and Technology, Division of Magnetic rusion Energy, Energy Research and Development Administration, Washington, DC 20545

55. Dr. Klaus Berkner, University of California, Lawrence Berkeley Laboratory, Berkeley, CA 94720

56. Dr. A. Cole, Culham Laboratory, UKAEA Research Group, Abingdon, Oxfordshire, OX14 3DB, England

57. Dr. W. S. Cooper, University of California, Lawrence Berkeley Laboratory, Berkeley, CA 94720

58. S. 0. Dean, Assistant Director, Office of Confinement Systems, Division of Magnetic Fusion Energy, Energy Research and Development Administration, Washington, DC. 20545

59. Harold K. Forsen, Exxon Nuclear Co., Inc., 777 106th Ave., NE, Bellevue, WA 98004

60. T. K. Fowler, University of California, Lawrence Livermore Laboratory, P.0. Box 808, Livermore, CA 94551 
61. H. P. Furth, Plasma Physics Laboratory, Princeton University, P.0. Box 451, Princeton, NJ 08540

62. Dr. C. Geller, CEA - Centre d'Etudes Nucleaire, Division of Plasma Physics, Grenoble, France

63. Dr. T. S. Green, Culham Laboratory, UKAEA Research Group, Abindgon, Oxfordshire, OX14 3DB, England

64. E. E. Kintner, Director, Division of Magnet1c Fusion Energy, Energy Research and Development Administration, Washington, DC 20545

65. Dr. E. H. Hooper, University of Californla, Lawrence Livermore Labortory, P.0. Box 808, Livermore, CA 94550

66. Dr. J. Junker, Max-Planck Inst1tut für Plasmaphys1k, Abteilung E2, 8046 Garching bei München, Federal Republic of Germany

67. Librarian, Culham Laboratory, UKAEA, Abingdon, Oxfordshire, 0x14 3DB, England

68. Librarian, Institut fur Plasmaphysik, 8046 Garching bei Munchen, Federal Republic of Germany

69. Plasma Physics Library, Plasma Physics Laboratory, Princeton University, P.0. Box 451, Princeton, NJ 08540

70. Shinzaburo Matsuda, Thermonuclear Library, Japan Atomic Energy Research Institute, Tokai, Naka, Ibaraki, Japan

71. T. Ohḳawa, Gulf-General Atomic, Inc., P.0. Box 608, San Diego, CA 92112

72. Dr. K. Prelec, Brookhaven National Laboratory, Upton, Long Island, NY 11973

73. Dr. R. V. Pyle, University of Calffornia, Lawrence Berkeley Laboratory, Berkeley, CA 94720

74. D. J. Rose, Department of Nuclear Engineering, Massachusetts Inst1tute of Technology, Cambridge, MA 02139

75. F. R. Scott, Electrical Power and Research Institute, 3412 Hiliview Ave., P.0. Box 10412, Palo Alto, CA 94303

76. N. N. Semashko, Kurchatov Atomic Energy Institute, Moscow, U.S.S.R.

77. TH. J. M. Sluyters, Brookhaven National Laboratory, Upton, Long Island, NY 11973 
78. D. R. Sweetman, Culham Laboratory, UKAEA Research Group, Abingdon, Oxfordshire, OX14 3DB, England

79. E. Thompson, Culham Laboratory, UKAEA Research Group, Abingdon, Oxfordshire, OX14 3DB, England

80. V. M. Tuchevich (Attn: V. E. Golant), A. F. Ioffe Physical Institute of the Academy of Sciences of the U.S.S.R., Leningrad K-21, U.S.S.R.

81-84. Dr. F. Valcx, DPH-PFC, Centre d'Etudes Nucleaires, BP No. 6, Fontenay-aux-Roses (Seine), France

85. J. M. Williams, Assistant Director, Development and Technology, Division of Magnetic Fusion Energy, Energy Research and Development Administration, Washington, DC 20545

86. J. T. Woo, Massachusetts Institute of Technology, Rm. 38-176, Cambridge, MA 02139

87. Dr. Herbert H. Woodson, Chairman, Department of Electrical Engineering, University of Texas at Austin, Austin, TX 78712

88. Director, Research and Technical Support Division, ERDA-ORO.

89-115. Technical Information Center, P.0. Box 62, Oak Ridge, TN 37830. 